\title{
Phytoremediation Potential of SENNA OCCIDENTALIS to remove Heavy metals from waste soil in Makurdi, Nigeria
}

\author{
Ogbodo O Juliana, ${ }^{*}$ Wuana A Raymond, ${ }^{1}$ T.A Tor-Anyiin ${ }^{2}$ Targema Rosemary Dooshima ${ }^{3}$ \\ *Department of Science Laboratory, Benue State Polytechnic P.M.B 01Ugbokolo, Benue state, Nigeria \\ 1 Department of Chemistry University of Agriculture P.M.B 2373 Makurdi, Benue State. \\ 2 Department of Chemistry University of Agriculture P.M.B 2373 Makurdi, Benue State. \\ 3 Department of Science Laboratory, Benue State Polytechnic P.M.B 01Ugbokolo, Benue state, Nigeria.
}

\begin{abstract}
This paper is aim to investigate the capacity of plant (Senna occidentalis) to remove contaminant in waste soil polluted by various heavy metals. The phytoextraction of $\mathrm{Cd}, \mathrm{Cu}, \mathrm{Ni}, \mathrm{Pb}, \mathrm{Zn}$ from waste dumpsite using Link plant (Senna occidentalis) was investigated under natural phytoextraction (NPE), chelant-assisted phytoextraction (CPE), Poultry manure-assisted phytoextraction (PMPE). Link plants were grown for 8 weeks in soils receiving: no treatment/amendments as NPE, citric acid (0.05 - $2.0 \mathrm{mmol})$ and EDTA (0.05 - $2.0 \mathrm{mmol})$ amendments as CPE, Poultry Manure $(2.0-10.0 \% \mathrm{w} / \mathrm{w})$ as PMPE. Post-harvest roots and shoots biomass (g) were 51.29 and 93.33 for NPE, (EDTA) ranged from 23.58 - 39.36 and 66.78 - 83.14, MPE ranged from 49.95 87.75 and 95.14 - 170.18. The percentage metal extractability in the various scenario followed the order, NPE; $\mathrm{Ni}>\mathrm{Cd}>\mathrm{Zn}>\mathrm{Cu}>\mathrm{Pb}, \mathrm{CPE}($ EDTA): $\mathrm{Zn}>\mathrm{Pb}>\mathrm{Cd}>\mathrm{Ni}>\mathrm{Cu}$, The BCF and TF was calculated for tissue metal concentrations, NPE showed that BCF for all metals were $<1$, TF for $\mathrm{Cd}(1.10)$ and $\mathrm{Ni}(2.59)$ were $>1 \mathrm{while} \mathrm{Cu}$, $\mathrm{Pb}$ and $\mathrm{Zn}$ were $<1$. EDTA CPE showed that BCF for all metals at all level of treatments were $<1$ while the TF were $>1$ for $\mathrm{Cd}(1.23,1.20,1.54$ and 1.11) $\mathrm{Cd}$ (1.30 and 1.07) and $\mathrm{Zn}(2.33$ and 1.91) while $\mathrm{Ni}$ and $\mathrm{Pb}$ were all $<1$. In general, S.occidentalis was capable of taking up all the Heavy metals under study, accumulating and adequately translocating them to the aboveground harvestable biomass provided the necessary soil amendment is done.
\end{abstract}

Keywords: Example (S.occidentalis, Phytorediation, Heavy metal and Natural Phytoextraction)

DOI: $10.7176 / \mathrm{CMR} / 11-4-05$

Publication date: April $30^{\text {th }} 2019$

\subsection{Introduction}

In most of the developing countries, it is common to find huge waste dumps within residential and industrial areas and on shoulders of minor and major roads owing to inadequate regulatory framework and enforcement system (Momodu et al., 2011). However, wastes comprises of all the unwanted materials arising from human and animal activities that are normally discarded as useless (Momodu et al., 2011).

These disposal sites have served as the final end for a wide range of organic and inorganic materials. The common types of waste materials found at dump sites includes household garbage and rubbish, market and household spoils and rotten food stuffs, farm waste and mills, street sweepings, construction and demolition debris, sanitation residues, industrial refuse, bio-medical solid waste, commercial refuse, dead plants and animals, abandoned vehicles and electronics (Udoakah and Akpan, 2013). Most, waste dump sites creates ugly sites in the cities; emit repulsive odours harmful to the human body and habours disease causing pests and pathogens (Lone, et al., 2008; Momodu, 2011; Bako et al., 2014). Industrial, municipal and domestic wastes are considered the main source of Heavy Metal pollution to the environment. (Lone et al., 2008; Momodu, 2011; Bako, 2014).

The plant Senna occidentalis L. has a common names: coffee senna, and belongs to the Family: Fabaceae (Leguminosae). It is Native to the tropical and subtropical regions of the America and was introduced to East and Western Africa (Barbadine, 2002; Dawson et al., 2008).

\subsection{Statement of the Problem}

Heavy metal from waste dumpsites can be washed into nearby surface water bodies around as well as leach into underground water and high levels of metals contaminants are frequently found in superficial soil and vegetation in areas where there is waste dump and removal of heavy metal from soil is the most technically difficult task.

Vegetables grown around such sites also have the tendency to phytoaccumulate heavy metals which are eaten by herbivores and eventually to humans and other forms of life through food web. Is it possible to remediate heavy metal contaminated waste dumpsites using phytoextraction method and could the plant Senna occidentalis L. be a good hyperaccumulator or serve as a phytoextractor of heavy metal contaminants from such site since they are found striving well around waste dump areas even when other plants can hardly survive. 


\subsection{Aim and Objectives of the Study}

The study is aimed at investigating the phytoremediation of heavy metals $(\mathrm{Cd}, \mathrm{Ni}, \mathrm{Pb}$, and $\mathrm{Zn})$ from a waste Dumpsite in Makurdi using Senna occidentalis L. plant.

The specific objectives are to:

(i) Characterize a waste dumpsite in makurdi.

(ii) Assess the potential of Senna occidentalis to phytoremediate selected heavy metals $(\mathrm{Cd}, \mathrm{Ni}$, $\mathrm{Pb}$, and $\mathrm{Zn}$ ) from the soil under natural phytoremediation and chelant (EDTA) assisted

\subsection{Significant of the Study}

Remediation of heavy metal polluted soils by conventional technologies (soil capping, soil washing, vitrification, etc.) previously developed for a small, heavily contaminated site is not adequate for large contaminated soils. Consequently, the need to investigate the use of the these plant Senna occidentalis L. as a low technology, in situ approach of phytoextraction to offer waste dumpsite restoration, partial decontamination, maintenance of the biological activity and physical structure of heavy metal contaminated waste dumpsites.

\subsection{Scope of the Study}

This research covers the use of link plant Senna occidentalis L. to phytoextract heavy metal specifically $\mathrm{Cd}, \mathrm{Cu}$, $\mathrm{Ni}, \mathrm{Pb}$ and $\mathrm{Zn}$ from a waste dumpsite located at welfare quarter in Makurdi, Nigeria.

\subsection{Experimental}

\subsection{Apparatus/ Instruments, Reagents and Chemicals}

The instruments and materials that were used during the analysis are as follows;

Laboratory materials: Beakers, measuring cylinder, stirrer, spatula, tongs sample bottles (made of Teflon or plastic), digestion vessels, porcelain crucibles, graduated pipette, volumetric flasks, conical flasks, stop watch, 2$\mathrm{mm}$ plastic sieve, porcelain mortar and pestle, What-man No 1 filter paper, hot plate, Hot Oven box for drying glasswares, weigh balance, metal spade, $\mathrm{pH}$ meter, Muffle Furnace, Fume Cupboard, dessicator and atomic absorption spectrometer (AAS) (AAS Bulk Scientific Model 6800).

\subsection{Study Area}

Waste dump site located at $7.44^{\circ} \mathrm{N}, 8.33^{\circ} \mathrm{E}$ in Lower Benue Basin, a major Agricultural activities in Makurdi Metropolis. Particularly at welfare quarter Makurdi, Nigeria. This waste dump site is surrounded by residential houses and several business activities.

\subsection{Sample Collection, Preparation and Characterization \\ 2.3.1 Soil sample}

The waste materials were cleared from the selected site in order to expose the soil beneath; soil sample was then collected using a stainless steel spade into polythene bags from depth of $0-15 \mathrm{~cm}$.

\subsubsection{Poultry manure}

Poultry droppings was collected from a livestock farm consisting of matured broilers into a polythene bag and transported to the garden. The poultry droppings collected were separated from the litter or rice husk, air-dried, ground into powder and then analyzed for pseudo total $\mathrm{Cd}, \mathrm{Cu}, \mathrm{Ni}, \mathrm{Pb}$ and $\mathrm{Zn}$ content and moisture content, $\mathrm{pH}$, and organic matter

Dried pod which contains the seeds were collected from the matured plant (Senna occidentalis L.) from areas producing them and taken to Forestry Department of the Federal University of Agriculture for identification.

\subsubsection{Pot Experiment with Senna occidentalis $L$.}

About $2 \mathrm{~kg}$ of soil sample was weighed into each pot. Then measured amount of poultry manure $(2,4,6$ and $10 \% \mathrm{w} / \mathrm{w}$ ) was added to the soil and mixed with a wooden stick, watered adequately and allowed to mature for two weeks. The seeds were then planted, kept in an open space (garden) and irrigated with distilled water until they grew visibly above the soil surface (about four weeks), five seeds were sown in each pot and later thinned to two and three depending on how healthy they looked. Measured amount $(0.05,0.15,1.5$ and 2.0 mmol) of the chelants (EDTA) were then added separately to the respective pots at five weeks of planting. A pot was left untreated as the natural scenario. Irrigation continued and the plants were monitored for another three weeks before harvesting. After 8 weeks of experiment, the plants were harvested separately. The harvested plant was washed and the above ground shoot was separated from the roots and plant biomass was computed on a per pot basis. The processed powder was subjected to acid digestion (Alinnor, 2004; Iyaka, 2007) and the concentration of the heavy metals $(\mathrm{Cd}, \mathrm{Cu}, \mathrm{Ni}, \mathrm{Pb}$ and $\mathrm{Zn})$ in the solutions was determined using atomic absorption spectrophotometer (Shimadzu G10) at National Research Instituite for Chemical Technology (NARICT), Zaria, Nigeria. 
3.3.4 Digestion of Senna occidentalis L. Biomass for Heavy Metal Analysis

About $5.0 \mathrm{~g}$ of each of the dried processed plant samples was digested in $50 \mathrm{~mL}$ of aqua-regia $\mathrm{HCl} / \mathrm{HNO}_{3}(3: 1)$ on a hot plate for about 90 minutes at $110^{\circ} \mathrm{C}$ to a gentle boil until the brown fumes disappeared. Then, $20 \mathrm{~mL}$ of distilled water was added and heated until a colorless (transparent) solution was obtained. (Alinnor, 2004; Iyaka, 2007).

\subsection{Results and Discussion}

3.1 Physicochemical Properties of the Soil and Manure used for the Analyses

Table 1: Some Physicochemical Properties of Waste Dump Soil Used For the Study.

\begin{tabular}{ll}
\hline Property & Value \\
\hline $\mathrm{pH}$ & $6.50 \pm 0.01$ \\
Texture & nil \\
Sand (\%) & $64.41 \pm 2.50$ \\
$\mathrm{Silt}(\%)$ & $19.54 \pm 1.90$ \\
Clay $(\%)$ & $16.05 \pm 0.51$ \\
Organic matter $(\%)$ & $16.30 \pm 0.54$ \\
Moisture content (\%) & $50.87 \pm 0.32$ \\
Water retention capacity (\%) & $7.02 \pm 0.72$ \\
Bulk Density $\left(\mathrm{g} / \mathrm{cm}^{3}\right)$ & $2.85 \pm 3.72$ \\
Cation exchange capacity (c/mol kg $\left.{ }^{-1}\right)$ & $6.31 \pm 0.91$ \\
Pseudototal metal $(\mathrm{mg} / \mathrm{kg})$ & \\
$\mathrm{Cd}$ & $6.48 \pm 1.13$ \\
& \\
$\mathrm{Cu}$ & \\
$\mathrm{Ni}$ & $508.24 \pm 1.22$ \\
$\mathrm{~Pb}$ & $20.60 \pm 0.26$ \\
$\mathrm{Zn}$ & $34.70 \pm 0.02$ \\
\hline
\end{tabular}

Table 2: Some Physicochemical Properties of Poultry Manure used for the Study

\begin{tabular}{ll}
\hline Property & Value \\
\hline $\mathrm{pH}$ & $6.90 \pm 0.90$ \\
Organic matter (\%) & $27.40 \pm 1.21$ \\
Water retention capacity (\%) & $12.00 \pm 2.74$ \\
Cation exchange capacity (cmol kg & -1 \\
Pseudo total metal $(\mathrm{mg} / \mathrm{kg})$ & $6.11 \pm 0.11$ \\
$\mathrm{Cd}$ & \\
$\mathrm{Cu}$ & $4.80 \pm 0.08$ \\
$\mathrm{Ni}$ & $529.02 \pm 2.60$ \\
$\mathrm{~Pb}$ & $5.80 \pm 0.07$ \\
$\mathrm{Zn}$ & $33.56 \pm 0.50$ \\
\hline
\end{tabular}

* Results recorded are mean of triplicate determinations \pm standard deviation. 
3.2 Fresh and Dry Weights of Plant Biomass after Harvest

Table 3: Fresh Weights (g) of Roots and Shoots of S.occidentalis under the Various Scenarios

\begin{tabular}{llll} 
Soil treatment & Dose & Root & Shoot \\
\hline \multirow{2}{*}{ Natural } & & & \\
& & 51.29 & 93.33 \\
EDTA(mmol) & 0.05 & 39.36 & 83.14 \\
& 0.15 & 38.65 & 70.36 \\
& 1.50 & 25.12 & 68.64 \\
& 2.00 & 23.58 & 66.78 \\
PM(\%w/w) & & & 95.14 \\
& 2.00 & 49.95 & 101.53 \\
& 4.00 & 58.36 & 120.26 \\
& 6.00 & 59.83 & 170.18 \\
AS & 10.0 & 87.75 & 115.18 \\
\hline
\end{tabular}

PM means poultry manure and AS means adjourning soil

Table 4: Dry Weights (g) of Roots and Shoots of S.occidentalis under the Various Scenarios

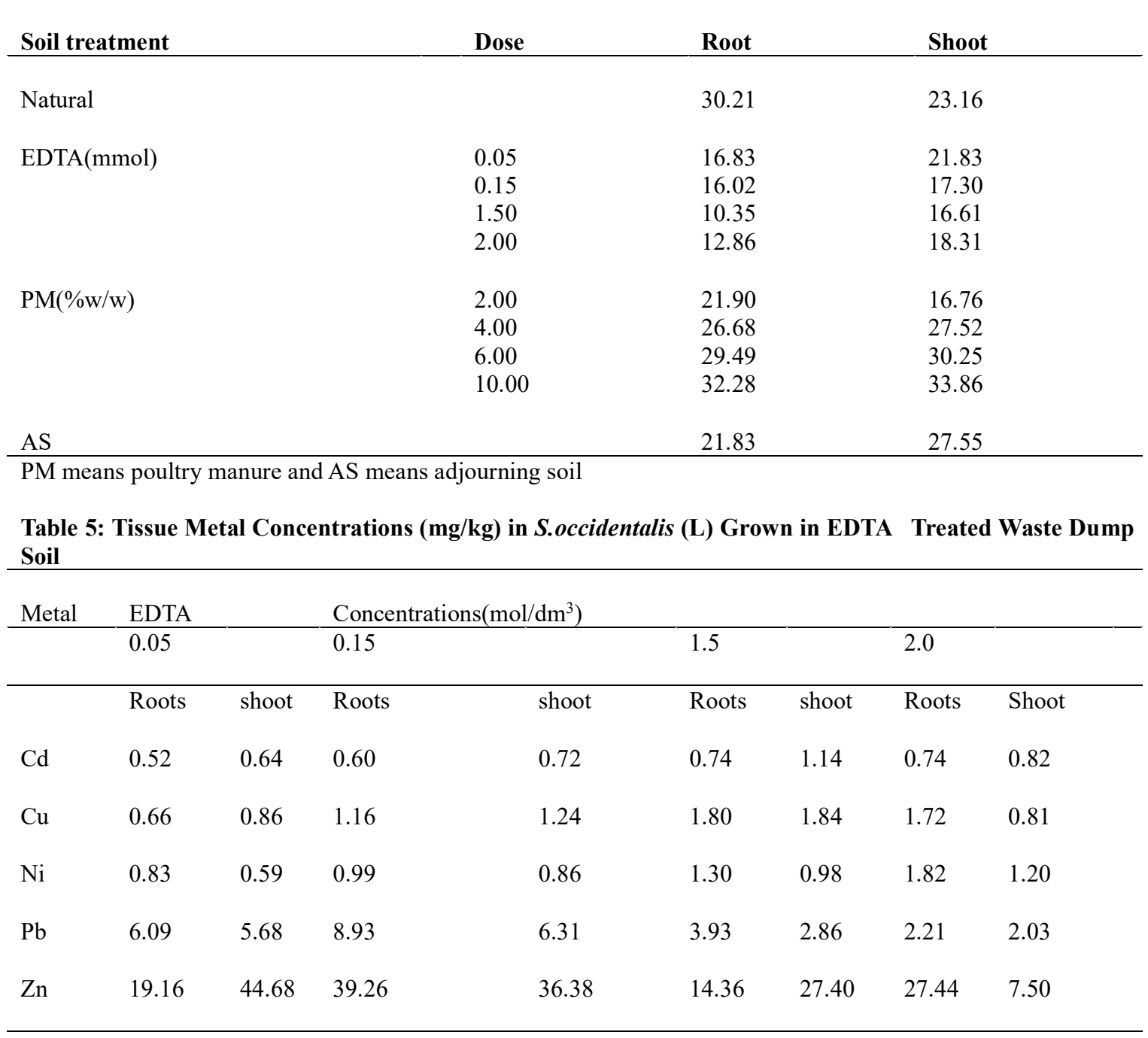


Table 6: BCF and TF for S. occidentalis (L) link Plant Grown in waste Dump Soil Treated with EDTA

Metal Level of Treatment $\left(\mathrm{mol} / \mathrm{dm}^{3}\right)$

\begin{tabular}{|c|c|c|c|c|c|c|c|c|}
\hline & & & & & \multicolumn{2}{|c|}{1.5} & 2.0 & \\
\hline 0.05 & & & & & & & & \\
\hline & $\mathrm{BCF}$ & TF & $\mathrm{BCF}$ & $\mathrm{TF}$ & $\mathrm{BCF}$ & $\mathrm{TF}$ & $\mathrm{BCF}$ & $\mathrm{TF}$ \\
\hline $\mathrm{Cd}$ & 0.179 & 1.231 & 0.204 & 1.200 & 0.290 & 1.541 & 0.241 & 1.108 \\
\hline $\mathrm{Cu}$ & 0.003 & 1.303 & 0.005 & 1.069 & 0.009 & 1.022 & 0.003 & 1.125 \\
\hline $\mathrm{Ni}$ & 0.069 & 0.711 & 0.185 & 0.905 & 0.111 & 0.754 & 0.147 & 0.659 \\
\hline $\mathrm{Pb}$ & 0.383 & 0.933 & 0.496 & 0.707 & 0.221 & 0.728 & 0.138 & 0.919 \\
\hline $\mathrm{Zn}$ & 0.662 & 2.332 & 0.784 & 0.927 & 0.433 & 1.908 & 0.365 & 0.270 \\
\hline
\end{tabular}

Table 7: Tissue Metal Concentrations (mg/kg) in S. occidentalis (L) Grown in Poultry Manure amended Waste Dump Soil

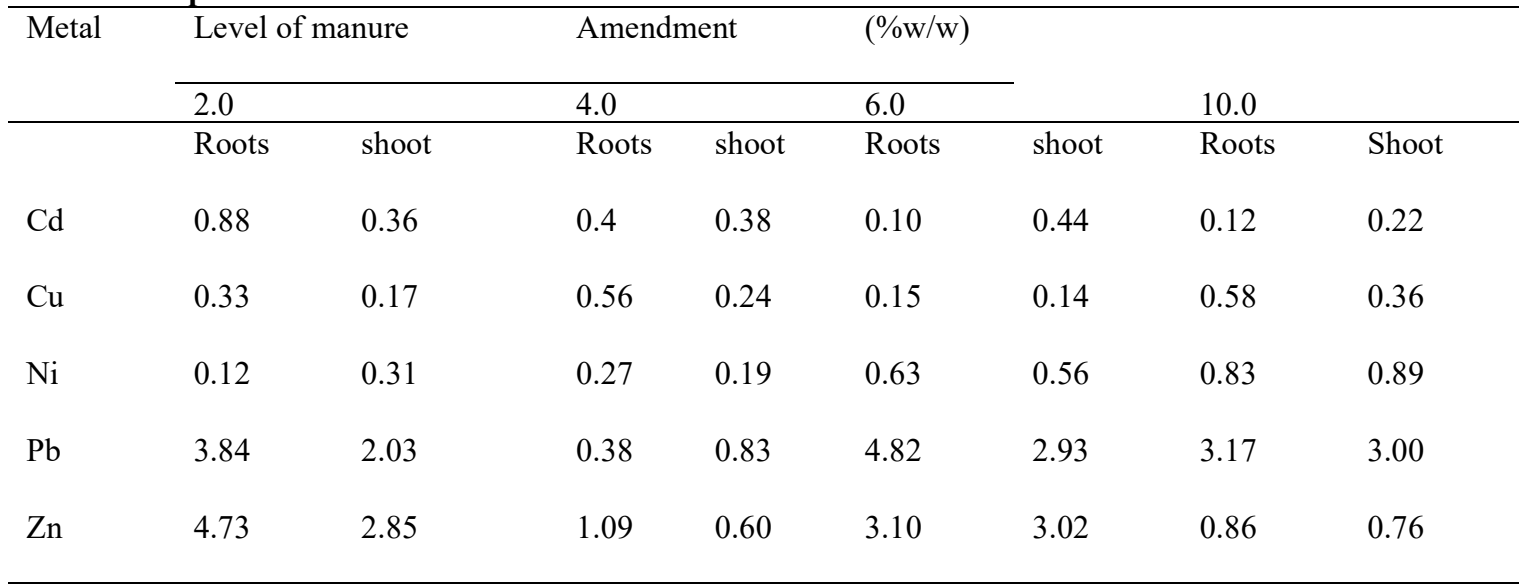

Table 8: BCF and TF for $S$. occidentalis (L) links Plant Grown in Waste Dump Soil Amended with Poultry Manure

\begin{tabular}{|c|c|c|c|c|c|c|c|c|}
\hline \multirow[t]{3}{*}{ Metal } & \multicolumn{4}{|c|}{$\begin{array}{l}\text { Level of Amendment (\% } \\
\mathrm{w} / \mathrm{w})\end{array}$} & \multirow{2}{*}{\multicolumn{2}{|c|}{6.0}} & \multirow{2}{*}{\multicolumn{2}{|c|}{10.0}} \\
\hline & 2.0 & & 4.0 & & & & & \\
\hline & $\mathrm{BCF}$ & $\mathrm{TF}$ & $\mathrm{BCF}$ & $\mathrm{TF}$ & $\mathrm{BCF}$ & $\mathrm{TF}$ & $\mathrm{BCF}$ & $\mathrm{TF}$ \\
\hline $\mathrm{Cd}$ & 0.191 & 0.409 & 0.069 & 0.950 & 0.031 & 4.400 & 0.030 & 1.833 \\
\hline $\mathrm{Cu}$ & 0.001 & 0.515 & 0.003 & 0.429 & 0.001 & 0.960 & 0.001 & 0.621 \\
\hline $\mathrm{Ni}$ & 0.016 & 2.583 & 0.017 & 0.704 & 0.021 & 0.889 & 0.065 & 1.072 \\
\hline $\mathrm{Pb}$ & 0.091 & 0.529 & 0.018 & 2.184 & 0.045 & 0.608 & 0.096 & 0.946 \\
\hline $\mathrm{Zn}$ & 0.044 & 0.603 & 0.017 & 0.550 & 0.036 & 0.974 & 0.009 & 0.884 \\
\hline
\end{tabular}




\subsection{Discussions}

The Results for the various analyses for the physicochemical properties carried out are presented in tables 1-3. From the result of the physicochemical properties of the waste dump soil used for analysis as presented in table 1 , the soil $\mathrm{pH}$ was found to be 6.5 . The texture of the soil has a proportion of $64.41 \%$ sand, $19.54 \%$ silt and $16.05 \%$ clay. The organic matter was $16.03 \%$. The moisture content was $50.87 \%$. The water retention capacity was $7.02 \%$, bulk density was $2.85 \mathrm{gcm}^{-3}$ cation exchange capacity was $6.31 \mathrm{c} / \mathrm{mol} \mathrm{kg}^{-1}$ and the pseudo total metal content $(\mathrm{mg} / \mathrm{kg})$ for $\mathrm{Cd}, \mathrm{Cu}, \mathrm{Ni}, \mathrm{Pb}$, and $\mathrm{Zn}$ were 6.48, 508.24, 20.60, 34.70 and 96.42 respectively. From table 2, Soil from the adjourning area has a pH of 6.28 and $5.86 \%$ organic matter, $38.94 \%$ moisture content, $4.83 \%$ water retention capacity, $1.56 \mathrm{gcm}^{-3}$ Bulk density and $3.85 \mathrm{c} / \mathrm{mol} \mathrm{kg}^{-1}$ cation exchange capacities. The texture of the soil gave a proportion of $67.59 \%$ sand, $18.81 \%$ silt and $13.60 \%$ clay and the pseudo total metal content $(\mathrm{mg} / \mathrm{kg})$ for $\mathrm{Cd}, \mathrm{Cu}, \mathrm{Ni}, \mathrm{Pb}$, and $\mathrm{Zn}$ were $0.31,28.51,14.82,7.34$ and 62.10 respectively.

The $\mathrm{pH}$ of the waste dump soil indicates that the soil is slightly acidic in nature. At low $\mathrm{pH}$, metals are more soluble and more mobile in the soil solution (David et al., 2009) hence toxicity problems are more severe than in alkaline soils. The result of the pH agrees with those of David et al., (2009), Tripathi and Misra, (2012) and Butheh et al., (2013).

The result also showed that the waste dump soil has an appreciable amount of the heavy metal contaminants under study but only $\mathrm{Cd}, \mathrm{Cu}$ and $\mathrm{Pb}$ has their values above maximum permissible limit according to the World Health Organization and European Union specification $(\mathrm{Cd}=0.3-0.35 \mathrm{mg} / \mathrm{kg}, \mathrm{Cu}=20-30 \mathrm{mg} / \mathrm{kg}, \mathrm{Ni}=75-80$ $\mathrm{mg} / \mathrm{kg}, \mathrm{Pb}=0.01 \mathrm{mg} / \mathrm{kg}$ and $\mathrm{Zn}=200 \mathrm{mg} / \mathrm{kg}$ ) for agricultural soil (WHO, 1996). This proves that the soil is actually contaminated with the stated heavy metals. The values for the heavy metal in the adjourning area all fall below the maxima for WHO and EU speciation and were all significantly $(\mathrm{p}<0.05)$ lower than those of the dumpsite. This is an indication that the adjourning soil is not contaminated with any of the heavy metal under study. There were significant differences $(p<0.05)$ between the individual metals determined. This is an indication that they must have occurred from different sources as the waste dump soil is heterogeneous in nature. From the result of fresh and dry weights $(\mathrm{g})$ of the plant materials both root and shoot as recorded in table 4 and 5 , The fresh weight $(\mathrm{g})$ of the roots and shoots of $S$. occidentalis $(L)$ grown in all scenarios ranged from 23.58 to 87.75 and 50.67 to 170.18 and the dry weights $(\mathrm{g})$ of roots and shoots ranged from 9.78 to 34.12 and 12.53 to 33.86 respectively.

$\mathrm{BCF}$ and $\mathrm{TF}$ are presented in tables 6 to 16 shows mean concentration $(\mathrm{mg} / \mathrm{kg})$ of Cd in roots ranged from 0.34 8.00 and ranged from $0.02-7.00 \mathrm{mg} / \mathrm{kg}$ in shoots. The highest value being recorded for both roots and shoots of plant grown in waste dump soil, whereas the percentage metal extractability in the natural phytoextraction followed the order $\mathrm{Ni}>\mathrm{Cd}>\mathrm{Zn}>\mathrm{Pb}>\mathrm{Cu}$ and the BCF for $S$. occidentalis $(L)$ grown in waste dump soil under Natural Phytoextraction were all $<1$ while the TF were $>1$ for $\mathrm{Cd}(1.1)$ and $\mathrm{Ni}(2.6)$ but $<1$ for $\mathrm{Cu}(0.2), \mathrm{Pb}$ (0.6) and $\mathrm{Zn}(0.2)$.

The percentage extractability with poultry manure amendment followed the order $\mathrm{Pb}>\mathrm{Cd}>\mathrm{Ni}>\mathrm{Zn}>\mathrm{Cu}$ and the $\mathrm{BCF}$ for $S$. occidentalis $(L)$ grown in waste dump soil amended with Poultry Manure all showed values $<1$ for all metals at all doses of amendment. The TF was $>1$ for $\mathrm{Cd}$ (at 6.0 and $10.0 \% \mathrm{w} / \mathrm{w}$ doses), $\mathrm{Ni}$ (at 2.0 and $10.0 \% \mathrm{w} / \mathrm{w}$ doses $), \mathrm{Pb}($ at $4.0 \% \mathrm{w} / \mathrm{w})$ but $<1$ for $\mathrm{Cu}$ and $\mathrm{Zn}$ at all doses.

\section{Conclusions}

The soil from the waste dumpsite is acidic sandy-loam soil with high organic matter, cation exchange capacity, water holding capacity and bulk density and contains heavy metal $(\mathrm{Cd}, \mathrm{Cu}, \mathrm{Ni}, \mathrm{Pb}$ and $\mathrm{Zn})$ contaminants with $\mathrm{Cd}, \mathrm{Cu}$, and $\mathrm{Pb}$ having values above maximium permissible limits for soils according to WHO and EU speciation. The metal phytoextracted were adequately translocated to the harvestable shoot of the plant. Thus $S$. occidentalis link plant showed a significant $(\mathrm{P}<0.05)$ phytoextraction potential for all the five metal considered in this study when the waste dump soil was used in six different scenarios hence it can serve as a phytoextractor for $\mathrm{Cd}, \mathrm{Cu}, \mathrm{Ni}, \mathrm{Pb}$ and $\mathrm{Zn}$ from waste dump soil when utilized in the appropriate scenario as considered.

\section{Acknowledgements}

I would like to express my biggest gratitude My Supervisor Prof. R. A. Wuana and my deepest appreciation is given to my dearest Husband Mr. Danduwa Emmanuel for his love and support.

\section{References}

Alinnor, J. I. (2004). Estimation of trace elements in leaves of Talium triangulare (waterleaf) and Varnoninaamy gdalina (bitter leaf) from major highways leading to Owerri. Nigerian Journal of Applied Science. 2: 
255-261.

Bako, S. P. Ezealor A. U. and Tanimu Y. (2014) Heavy Metal Deposition in risk assessment as a conservation tool to identify invasive plant threats in East African rainforests. Journal of Biological Conservation. 142: $1018-1024$.

Barbadine (2002) Senna occidentalis (L.) Reunion Island France. http://www.barbadine.com/pages/senna_occ_lien.htm.

Buteh, D. S., Chindo, I. Y., Ekanem, E. O and Williams, (2013). Impact Assessment Soils and Plants Impacted by Anthropogenic Modification of Two Sites in the SudanSavanna of North Western Nigeria, INTECH Open Science 697-722.

David, N. O., Benjamin, L. K. and Patrick, O. Y. (2009). Some Physicochemical and Heavy Metal Level in Soils of Waste Dump Sites in Port Harcourt Municipality and Environs. Journal of Applied Science and EnvironmentalManagement. 13 (4): 65 - 70.

Dawson, W., Burslem, D. F. R. P. and Hulme, P. E. (2009). The suitability of weed dumpsites in relation to their soil properties: Identification of adaptive plants. Bulletin of Environmental and Scientific Research 1 (2): 1-10. Engineers (IEEE) Global Humanitarian Technology Conference (GHTC) USA 1- 4.

Iyaka, Y.A. (2007). Concentration of $\mathrm{Cu}$ and $\mathrm{Zn}$ in some fruits and vegetables commonly available in North Central Zone of Nigeria. Journal of Environmental Agriculture and Food Chemistry. 6: 2150- 2154.

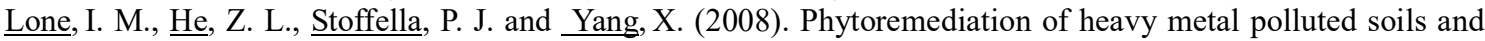
water: Progresses and perspectives. Journal of Zhejiang University Science 9 (3): 210-220.

Momodu, N.S., Dimuna, K. O. and Dimuna, J. E (2011). Mitigating the Impact of Solid Wastes in Urban Centres in Nigeria. Journal of Human Ecology. 34(2): 125-133.

Tripathi, A. and Misra, D. R. (2012). Floral distributions at municipal waste of Contamination Pattern of Solid Waste Dumpsites Soil: A Comparative Study of Bauchi Metropolis. World Journal of Analytical Chemistry. 1 (4): 59-62.

Udoakah, Y. and Akpan U. (2013). A Sustainable Approach to Municipal Solid Waste Management in Southern Nigeria. Institute of Electrical Electronics 